\title{
Biochar improves soil physical characteristics and strengthens root architecture in Muscadine grape (Vitis rotundifolia L.)
}

Yuru Chang ${ }^{1}$, Lorenzo Rossi ${ }^{2}$, Lincoln Zotarelli ${ }^{1}$, Bin Gao ${ }^{3}$, Muhammad Adnan Shahid ${ }^{4}$ and Ali Sarkhosh ${ }^{*}$

\begin{abstract}
Background: Biochar is widely assumed as an effective soil amendment. It improves soil structure and fertility, thereby enhancing crop growth and development. There is still a knowledge gap in research on the beneficial impact of biochar on root growth and root architecture in perennial woody plants. Therefore, in our 14-week greenhouse study, pinewood-based biochar was applied as soil amendment for muscadine grape cultivation to investigate its effects on soil physical properties and crop root growth. Muscadine grape cv. Alachua was grown on Ultisols soil mixed with five rates of biochar on weight basis. Soil mixture properties and root attributes were determined.

Results: The soil bulk density decreased $40 \%$ and the total porosity increased $50 \%$ by adding $20 \%$ biochar into pure sandy soil. The soil water-holding capacity (WHC) of 20\% biochar amendment soil was 1.9 times as pure as sandy soil. In addition, the incorporation of biochar did not only ameliorate soil acidity at the beginning but also increased soil pH buffering capacity, providing suitable soil pH a few months after application. Moreover, biochar induced woody plant finer roots development and significantly promoted root length, number of root forks, and crossings, while decreasing root average diameter.

Conclusions: Pinewood biochar significantly improved soil physical properties by moderating soil thermal properties, buffering soil pH, improving soil WHC, decreasing soil bulk density, and increasing soil porosity. In addition, biochar also strengthened the root architecture by improving root length, number of root forks, and crossings. Furthermore, roots from the amended treatment had longer root length with less average diameter than unamended roots, indicating that biochar may stimulate muscadine fine root development. The incorporation of biochar in soil enhanced woody plant root growth and development improved soil structure in sandy soils. It could potentially be a good strategy to tackle water loss, particularly in sandy soils.
\end{abstract}

Keywords: Biochar, Leachate pH, Root architecture, Ultisols soil, Soil water-holding capacity

\section{Background}

Biochar, also named "agrichar," is a relatively stable carbon compound formed by the thermal decomposition of various biomass materials under low oxygen conditions $[1,2]$. The use of biochar as amendment can improve water and nutrient retention in soil and stimulate plant

\footnotetext{
*Correspondence: sarkhosha@ufl.edu

${ }^{1}$ Horticultural Sciences Department, University of Florida, Gainesville, FL 32611, USA

Full list of author information is available at the end of the article
}

growth [3-5]. In the southeastern United States, sandy soil is a typical soil type of the "Ultisols." Its limited water-holding capacity (WHC) led to leaching of water and nutrients [6]. Recently, biochar-related research is increasing rapidly and many benefits of soil amendment on Ultisols soil have been intensively investigated, including enhancing chemical and physical characteristics as well as fertility of soils [7]. Therefore, biochar is considered as one of the potential solutions to improve soil fertility and crop production in sandy soils. 
Most of the work done on biochar amendment focused on plant aboveground growth and yield, but very few on root architecture [8-10]. Plant root systems play an important role in plant growth as they are the first contact point between biochar particles and growing plants when absorbing water and nutrients [11]. Thus, biochar application may change root morphology, functioning, and hence affect plant performance. Therefore, it is important to determine how root traits respond to biochar application in sustainable soil management practice $[12,13]$.

Biochar can improve root-soil interactions in distinct root-soil zones for increasing root activity [11, 14]. Biochar-induced improvement in root growth and development may be associated with at least two mechanisms: (i) enhanced nutrient supply by serving as a direct nutrient source and (ii) helped increase nutrient retention and availability in the rhizosphere and bulk soils [14]. Biochar incorporation rate is highly dependent of crop and soil type. An optimal amount of biochar in sandy soil for turfgrass is close to $10 \%(\mathrm{v} / \mathrm{v})$ considering root depth and soil WHC. Incorporation of more than $10 \%$ biochar in sandy soils may detrimentally affect plant root depth. It may be because of anaerobic conditions which are due to higher soil water retention and less oxygen in pore space [15].

Soil amendment with biochar was found to be very effective in improving soil WHC [16-19], soil water infiltration [20,21], soil water availability [22], nutrient retention [23, 24], soil hydraulic conductivity [25], and soil aeration [26, 27]. In addition, biochar can increase soil microbial activity $[28,29]$, cause shifts in microbial diversity [30], increase soil electrical conductivity [31], and immobilize contaminants, such as trace elements, like copper [21, 25, 32] or pesticides [33, 34]. Therefore, the use of biochar in grape production under sandy soils could facilitate nutrient and irrigation management practices.

Muscadine grapes (Vitis rotundifolia. L., Vitaceae) are the predominant grape cultivar commonly grown in the southeastern United States, with current markets existing for juice, wine, and fresh fruit. The Vitis genus is divided into two subgenera: Euvitis (the European grapes, Vitis vinifera L. grapes, and the American bunch grapes, Vitis labrusca L.) and Muscadinia (the Muscadine grapes Vitis rotundifolia L.) $[35,36]$. Muscadine grapes are round, having either bronze- or purple-colored leather-like thick skin, and are well adapted to warm, humid climates, which are not suitable for growing table grapes (Vitis Vinifera L.) [37]. Native muscadine grapes have a distinct benefit compared with table grapes. Firstly, muscadines need fewer chilling hours than other grape cultivars so that they can thrive on the summer heat [38]. Secondly, they have a natural resistance to Pierce's disease, which is caused by the bacterial pathogen, Xylella fastidiosa [39]. This pathogen prevents the extensive cultivation of $V$. Vinifera in Florida.

A high correlation between developments of the underground and aboveground parts of grapevines has been demonstrated [40]; thus, studying the impact of biochar on root morphological attributes would be helpful for understanding plant-soil interactions and their ultimate impact on plant growth. We tested the hypothesis that biochar incorporation in sandy soils can improve soil physical properties and make root architecture stronger in muscadine grape.

\section{Materials and methods}

\section{Site and description of the experimental materials}

The research was conducted in a greenhouse at the University of Florida Plant Science Research and Education Unit (Latitude $29.40 \mathrm{~N}$, Longitude 82.17 W, Altitude $21 \mathrm{~m}$ ) in Citra, FL. Soil for this study was collected from the organic area in Plant Science Research and Education Unit at $0-30 \mathrm{~cm}$ depth, which means the soil is free from herbicides and pesticide residuals. The soil type at the site is characterized as Ultisols, which is acidic and strongly leached. The soil texture was classified as sandy soil with $972 \mathrm{~g} \mathrm{~kg}^{-1}$ of sand, $24 \mathrm{~g} \mathrm{~kg}^{-1}$ of silt, and $4 \mathrm{~g} \mathrm{~kg}^{-1}$ of clay. "Alachua," a widely planted muscadine grape cultivar, was used in this experiment. One-month-old tissue-cultured vines were provided by AgriStarts propagating nursery (Lakeland, FL, USA). The activated biochar produced by pyrolysis of southern yellow pine at $400{ }^{\circ} \mathrm{C}$ was provided by Mirimichi Green Express, LLC (Castle Hayne, NC, USA). This biochar had a pH of 6.2 and its particle size was evenly distributed between 0.6 to $10 \mathrm{~mm}$ with less than $4 \%$ ash. It had active carbon of $526 \mathrm{mg} \mathrm{Kg}$, $\mathrm{C} / \mathrm{N}$ ratio of 30:1, and cation exchange capacity (CEC) of $20.13 \mathrm{meq} 100 \mathrm{~g}^{-1}$. In addition, it had surface area of $366.14 \mathrm{~m}^{2} \mathrm{~g}^{-1}$, and density of $1.89 \mathrm{~g} \mathrm{~cm}^{-3}$.

\section{Experimental design}

Biochar was applied and incorporated into the soil, three days before planting, at rates of $5 \%, 10 \%, 15 \%$, and $20 \%$ dry weight basis. A control treatment using soil with no biochar load was conducted to compare with the other treatments which incorporated different rates of biochar. Afterward, the volume of total potting media across biochar rate gradient was adjusted to a constant. Each of the five ratios of sandy soil and biochar was thoroughly and gently mixed by hand to avoid damaging biochar particle structure. Each rate has six replications, with two plants in each replication.

Experiment 1: Muscadine plants were planted individually in 5.7-L pots filled with the five different proportions of biochar-soil mixtures. The experiment was laid out in 
randomized complete block design with five treatments, and each treatment was replicated six times (two plants per replicate).

Experiment 2: In the column study, twenty soil columns $\left(10 \mathrm{~cm}\right.$ internal diameter by $100 \mathrm{~cm}$ length $\left.=31,400 \mathrm{~cm}^{3}\right)$ made of white polyethylene pipes supported by a wooden table were used. A piece of fine wire mesh was attached to the column bottom to prevent losing soil mixtures and to let water drain down freely. Columns were filled up with five rates of biochar mixtures $(0 \%, 5 \%, 10 \%, 15 \%$, and $20 \%$, based on weight) in four replicates. Each column was planted with one muscadine plant. The environmental conditions as well as the irrigation and fertilization schedules were all the same with the pot experiment. At the end of the experiment, all muscadines were destructively harvested for root and aboveground analysis, 16 weeks after transplant.

The greenhouse study in pots was conducted to determine the optimum biochar amendment rate, which also provided wider and shallower space. The column study provided longer and narrower space for grape root development, allowed easier collection of leached water, and reduced overlapping and competition of roots. In this way, the research gap on biochar in relation to root architecture can be minimized.

\section{Cultural practices}

The air temperature of the greenhouse was set between 18 and $26{ }^{\circ} \mathrm{C}$. Fertilizer was applied weekly through the irrigation system at $1.5 \%$ rate with nitrogen-phosphorouspotassium plus trace elements (15-5-15 + TE, elements, Peters, PA, USA). For muscadine plants in pots, there was one dripper in each pot, with a flow rate of $40 \mathrm{~mL} \mathrm{~min}$. The irrigation system was set to irrigate three times a day, at 8:00 am, 2:00 pm, and 8:00 pm. The plants were irrigated one minute each time $\left(120 \mathrm{~mL} \mathrm{day}^{-1}\right)$ in the first 8 weeks, two minutes each time $\left(240 \mathrm{~mL} \mathrm{day}^{-1}\right)$ in weeks 9 and 10 , and three minutes each time $\left(360 \mathrm{~mL}^{-1 a y}{ }^{-1}\right)$ starting from week 11 to the end of the trial (week 14). The $\mathrm{pH}$ of irrigation water is around 8 . The trellis system was installed to support grape growth two weeks after transplanting.

\section{Measurement of soil properties}

Soil temperature in pots was measured monthly at a depth of $15 \mathrm{~cm}$ using a digital lab thermometer with stainless steel probe (DT301LAB stem thermometer, General Tools, NY, USA). Additionally, in the column study, the irrigation was turned on manually for half an hour and the leachate was collected to measure $\mathrm{pH}$ value monthly, lasting for three months. Exudates $(50 \mathrm{~mL})$ collected at the bottom of each column were taken to the lab and their $\mathrm{pH}$ was measured at room temperature with a digital $\mathrm{pH}$ meter (FE20-Basic benchtop digital $\mathrm{pH}$ meter, Mettler Toledo, $\mathrm{OH}, \mathrm{US}$ ).
The other soil physical properties, including soil WHC, soil bulk density, and soil porosity, were measured with soil samples from pots. Soil moisture was determined gravimetrically from the mixed samples from each plot at the end of the study. All samples were air-dried and evenly mixed. The soil samples $(50 \mathrm{~g})$ were weighed and packed into funnels covered with filter paper to prevent the loss of soil or biochar. All filter papers were saturated with deionized water. Next, $50 \mathrm{~mL}$ of water was gradually added to each soil sample. A beaker was used to collect the leachate water for 30 min until there was no drain at room temperature. The top of the funnel was covered by a plastic wrap to prevent the water loss by evaporation [41, 42]. Finally, with a known leachate water volume, soil WHC was calculated as follows [6]:

$$
\begin{aligned}
\mathrm{WHC}= & \frac{\text { Total water added }- \text { Volume of water run down }}{\text { Dry weight of soil sample }} \\
& \times 100 \%,
\end{aligned}
$$

where WHC represents the water-holding capacity.

Soil bulk density was determined at the end of the experiment from one pooled sample from each treatment. Total porosity was calculated from soil bulk densities by the following expression:

$$
P=\frac{\text { Volume of voids }}{\text { Total volume }} \times 100 \%
$$

where $\mathrm{P}$ represents the total porosity. This equation can also be transformed into:

$$
p=\left(1-\frac{\mathrm{BD}}{\mathrm{PD}}\right) \times 100 \%
$$

where $\mathrm{BD}$ is the bulk density and PD is the particle density. The soil particle density (PD) can be calculated from as follows:

$$
P D=\frac{\text { Mass of sample }}{\text { Volume of sample }} \times 100 \% .
$$

However, the soil particle density is always assumed to be $2.65 \mathrm{~g} \mathrm{~cm}^{-3}$ for any soil sample [43]. Based on this, we calculate total porosity as follows:

$$
P=\left(1-\frac{\mathrm{BD}}{2.65 \mathrm{~g} / \mathrm{cm}^{3}}\right) \times 100 \% .
$$

\section{Determination of root architecture}

In the pot study, the roots were separated by breaking the pots from the two sides. In the column study, the columns were laid down and the roots were gently 
pulled out by hand. The roots were then submerged in tap water, rinsed with mild water flow, and soaked in deionized water until scanned. Root scanner (Epson 12000XL, Seiko Epson Corporation, Nagano, Japan) and WinRHIZO software (WinRHIZO Pro, Regent Instruments, $\mathrm{QC}$, Canada) were used to measure total root length, average root diameter, specific root length, root volume, and number of crossings.

\section{Statistical analysis}

All collected data were analyzed using Proc GLIMMIX (General Linear Mixed Model) in SAS statistical software (ANOVA SAS 9.1, SAS Institute, Cary, NC, USA). We assumed a Gaussian response distribution, and the default covariance matrix format was used to compare treatment means. Type III tests of fixed effects were used to examine main effects for each treatment. Mean separation was accomplished with the Tukey-Kramer honest significant difference test $(\alpha=0.05)$. In all cases, assumptions of normal distribution and equal variance were validated by diagnostic plots generated from the GLIMMIX procedure.

\section{Results and discussion}

\section{Evaluation of soil properties}

Data on soil temperature from the first two measurements depicted a negative correlation between soil temperature and rate of biochar incorporation (Table 1). However, the third-time measurement showed a down trend, although no statistically significant difference was found among the groups. The results corroborated with a previous study in which the thermal conductivity of soil decreased significantly by $3.5 \%$ and $7.5 \%$, with 4.5 and $9.0 \mathrm{Mg} \mathrm{ha}{ }^{-1} \mathrm{yr}^{-1}$ in response to increment in biochar rate, respectively [44]. This was also consistent with the decrease in soil bulk density. Authors [44] also reported that biochar treatment may regulate the extreme soil temperature, reducing the temperature when the soil temperature is high and raising it when soil temperature is low. The adjustment capability of soil daily average temperature and diurnal range was mostly within $\pm 0.4{ }^{\circ} \mathrm{C}$ and $\pm 0.8^{\circ} \mathrm{C}$, respectively. Regulation of soil temperature by biochar can be understood by the synergistic reaction of changes in soil thermal conductivity and reflectance [44].

Soil bulk density decreased, while WHC and total porosity increased gradually with the increase in biochar rate (Table 2) and a significant positive correlation between WHC and biochar application rate is observed when the biochar application rate was below $20 \%$. The WHC of $20 \%$ biochar-amended soil reached $52 \%$, while pure sandy soil only had WHC of $28 \%$. Biochar significantly increased WHC by more than $50 \%$, compared to the controls. Soil WHC was increased by $1.2 \%$ by mass for each $1 \%$ addition of biochar over the agriculturally relevant range up to $20 \%$ biochar concentrations. Yu et al. reported that WHC of loamy sand soil mixed with different proportions of yellow pinewood biochar had a positive correlation between WHC and percent of biochar amendment for biochar concentrations below $10 \%$. In addition, the increase in WHC per unit of biochar amendment was increased when biochar concentrations were below $10 \%$, but was constant at $12 \%$ when biochar concentration was beyond $10 \%$. Thus, it was suggested that $10 \%$ amendment maximizes the water holding value

\begin{tabular}{|c|c|c|c|}
\hline $\begin{array}{l}\text { Biochar rate } \\
\%\end{array}$ & $\begin{array}{l}\text { Water-holding } \\
\text { capacity }(\%)^{\mathrm{a}}\end{array}$ & $\begin{array}{l}\text { Bulk density (g } \\
\mathrm{cm}^{-3} \text { ) }\end{array}$ & $\begin{array}{l}\text { Total porosity } \\
\text { (\%) }\end{array}$ \\
\hline 0 & 28 & 1.47 & 45 \\
\hline 5 & 34 & 1.21 & 54 \\
\hline 10 & 40 & 1.08 & 60 \\
\hline 15 & 46 & 1.02 & 62 \\
\hline 20 & 52 & 0.88 & 67 \\
\hline
\end{tabular}

a Water-holding capacity (WHC) $(n=3)$ and bulk density were determined from unsieved soil samples at the end of the experiment. Total porosity was calculated from bulk densities assuming a $2.66 \mathrm{~g} / \mathrm{cm}^{3}$ particle density for soil minerals. Three replicate samples from the pool of each treatment were used to determine statistical uncertainty

Table 1 Soil temperature measured in May, June, and July, respectively

\begin{tabular}{|c|c|c|c|c|c|c|}
\hline Biochar rate \% & 19-May & & 19-Jun & & 19-Jul & \\
\hline 0 & 26.1 & $a^{a}$ & 29.7 & a & 31.2 & a \\
\hline 5 & 26.0 & $a b$ & 29.1 & $a b$ & 30.9 & a \\
\hline 10 & 25.2 & c & 29.1 & $a b$ & 30.7 & a \\
\hline 15 & 25.6 & $b c$ & 28.8 & $b$ & 30.7 & a \\
\hline 20 & 25.3 & C & 29.0 & $a b$ & 30.8 & a \\
\hline
\end{tabular}

${ }^{a}$ Least square means followed by the same letters are not significantly different $(P \leq 0.05)$ according to the Tukey-Kramer test 

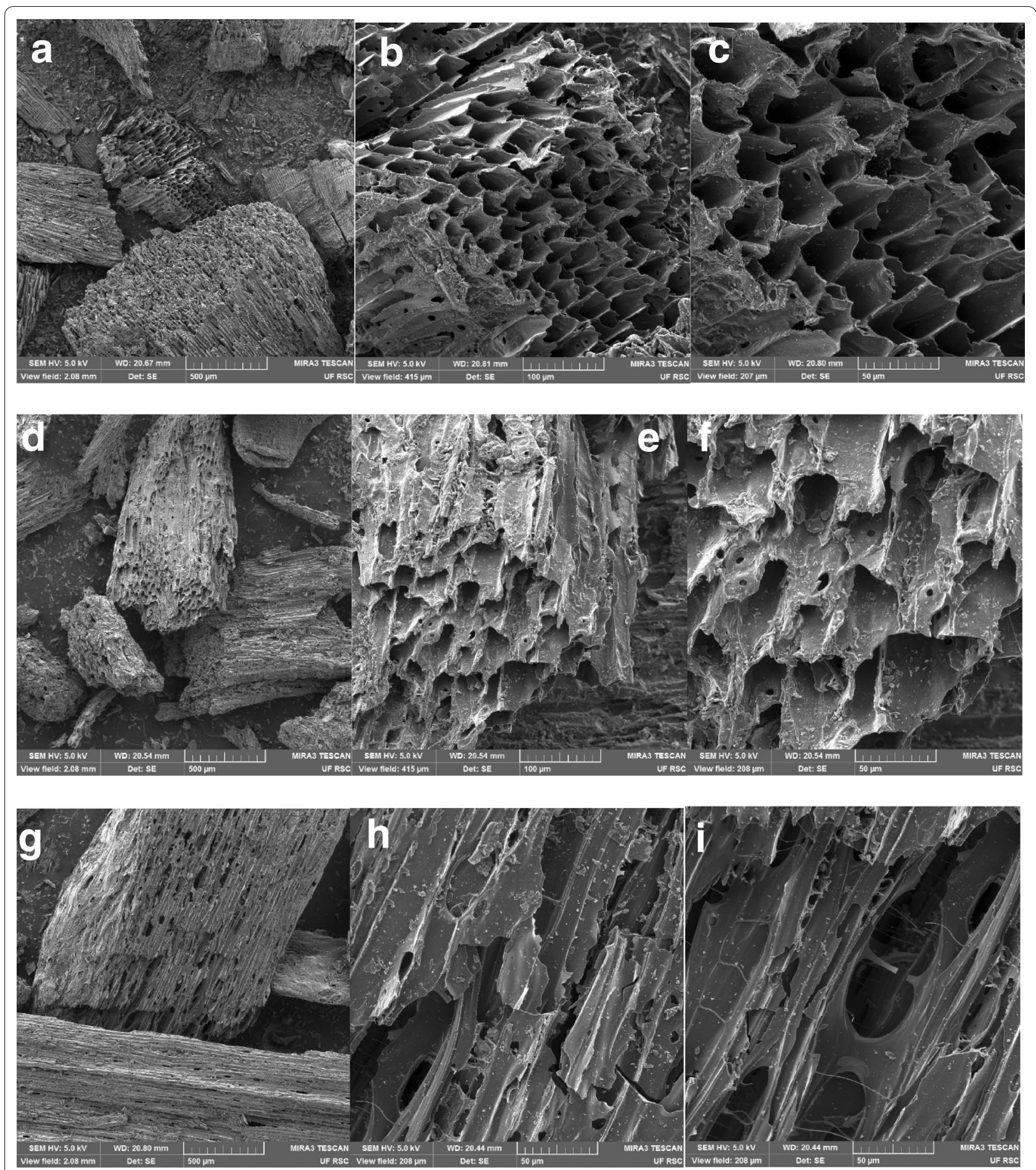

Fig. 1 SEM images (bar $50 \mu m ; \times 1000$ magnification) of the pinewood biochar particles at $100 \times(\mathbf{a}, \mathbf{d}, \mathbf{j}), 500 \times(\mathbf{b}, \mathbf{e}, \mathbf{h})$, and $1000 \times(\mathbf{c}, \mathbf{f}, \mathbf{i})$

magnifications 
of single percent of biochar. It was also reported that the standard deviation showed very little variance in biochar rates up to $20 \%$, but gradually increased as the biochar amendment rate increased [6].

The modification of biochar has two effects on soil WHC [45]. Firstly, biochar itself can retain water in its internal pores, thus directly increasing soil moisture content. The scanning electron microscopy (SEM) micrographs of the pinewood biochar particles at $100 \times$, $500 \times$, and $1000 \times$ magnification are shown in Fig. 1 . An earlier study on straw biochar confirmed that the presence of pores, with diameters between 0.1 and $10 \mu \mathrm{m}$, in the biochar enhances the percentage of plant available water. In addition, other factors, such as the total pore volume and hydrophilic functional groups on the surface of biochar, may also help improve soil WHC, although these effects may be limited considering the tiny amount of biochar added to the soil.

Biochar particles can reduce the overall bulk density of sandy soils (Table 2). Specifically, the bulk density of sandy soil was reduced more by small biochar particles, while the bulk density of loamy sand soil was reduced more by large biochar particles [46]. A decrease in biochar particle size can increase water retention, but may reduce saturated water flow [46]. Modulations in bulk density for the biochar treatments along the incubation period were not always significant [47]. The changes in mixed soil bulk density may result from the low bulk density of the biochar itself [48]. Biochar and soil physical property data mentioned in the study showed that biochar generally reduces soil bulk density by 3 to $31 \%$, increases porosity by 14 to $64 \%$, and increases wet aggregate stability by 3 to $226 \%$. Biochar appears to improve soil properties of sandy soils more than clayey soils [46].

The influence of biochar on soil physical properties can directly affect muscadine growth because the penetration depth and accessibility of air and water in the root zone mostly depend on soil physical composition. It can further affect the ability of the soil to react to water, its aggregation, dynamics, and permeability at expansion, as well as its ability to maintain cations and respond to $\mathrm{pH}$ changes [3].

The $\mathrm{pH}$ value of leachate is shown in Table 3 . The soil used in the current study had $\mathrm{pH}$ of 5.7. The data of the measurement in April demonstrated that the leachate $\mathrm{pH}$ increased with the increase of biochar percentage. In the measurement in June, leachate $\mathrm{pH}$ decreased, which was due to the application of nitrogen fertilizer. In the measurement in August, the leachate $\mathrm{pH}$ increased, which was mainly due to irrigation. After four months, leachate $\mathrm{pH}$ of the soils receiving biochar was between 6.4 and 7.1. It was very close to the optimum $\mathrm{pH}$ for muscadine growth, which is 6.5. After five months, the leachate $\mathrm{pH}$ of soil from control treatment began to reach 6.3, while the leachate $\mathrm{pH}$ of modified soil stabilized at about 6.9. This is consistent with numerous studies in which the use of biochar increased the pH of acidic soils [49]. Furthermore, soil pH can affect nutrient availability. For example, maximum phosphorous $(\mathrm{P})$ availability is near $\mathrm{pH} 6.5[50,51]$. $\mathrm{P}$ becomes insoluble phosphorous/aluminum minerals at low $\mathrm{pH}$ and forms calcium-phosphate solid mineral at high $\mathrm{pH}$. Besides, potassium, calcium, and magnesium are less available in acid soils because of leaching [52]. Moreover, the three measurements showed that the leachate $\mathrm{pH}$ of the control group increased over time, while that of the biochar treatments remained at similar value. It indicated that the incorporation of biochar did not only ameliorate soil acidity but also increased soil pH buffering capacity. The principal mechanism for the increase of $\mathrm{pH}$ buffering capacity of acid soils with the incorporation of biochar is the protonation and deprotonation of oxygen-containing functional groups in biochar. These oxygen-containing functional groups can absorb and provide protons through an association reaction of low $\mathrm{pH}$ and dissociation reaction of high $\mathrm{pH}$, thus buffering the change of soil $\mathrm{pH}[53]$.

\section{Evaluation of root architecture}

The results of the pot experiment showed that biochar application significantly increased not only root length, root project area, and surface area but also root

Table 3 Soil pH measured from leachate monthly in column study from April to August in 2019

\begin{tabular}{|c|c|c|c|c|c|c|}
\hline Biochar rate \% & 19-Apr & & 19-Jun & & 19-Aug & \\
\hline 0 & 5.75 & $D^{a}$ & 4.89 & C & 6.27 & $b$ \\
\hline 5 & 6.47 & C & 6.43 & $\mathrm{~b}$ & 6.82 & $a b$ \\
\hline 10 & 6.73 & $b$ & 6.81 & $a b$ & 6.94 & $a$ \\
\hline 15 & 6.73 & $b$ & 7.16 & $\mathrm{a}$ & 6.99 & a \\
\hline 20 & 6.87 & a & 7.11 & $\mathrm{a}$ & 6.92 & $\mathrm{a}$ \\
\hline
\end{tabular}

${ }^{a}$ Least square means followed by the same letters are not significantly different $(P \leq 0.05)$ according to the Tukey-Kramer test 


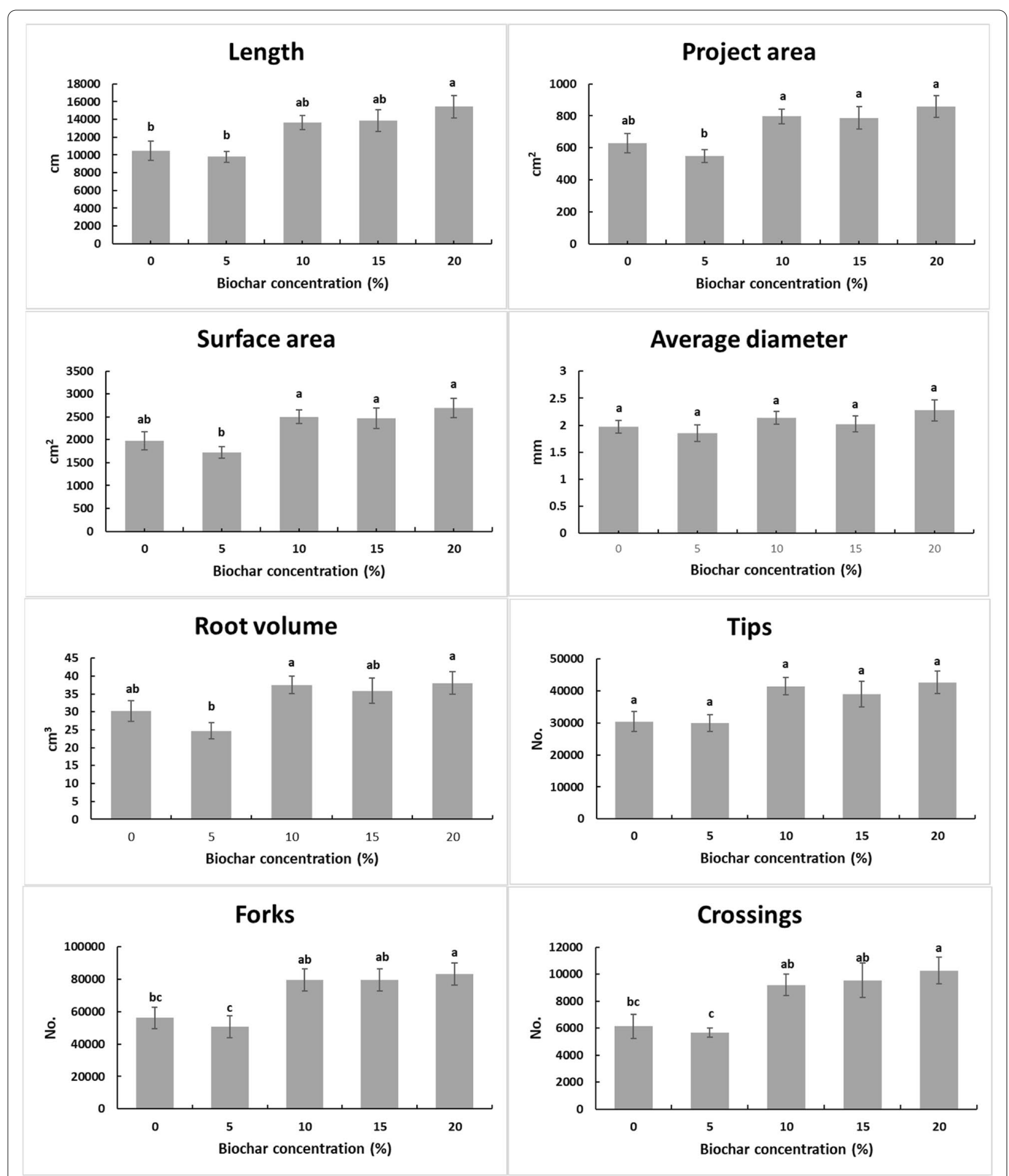

Fig. 2 Root traits from pot experiment obtained from WinRhizo software (WinRHIZO Pro, Instruments Regent, QC, Canada). Bars with the same letters indicate that the least square means are not significantly different $(P \leq 0.05)$, according to the Tukey-Kramer test 


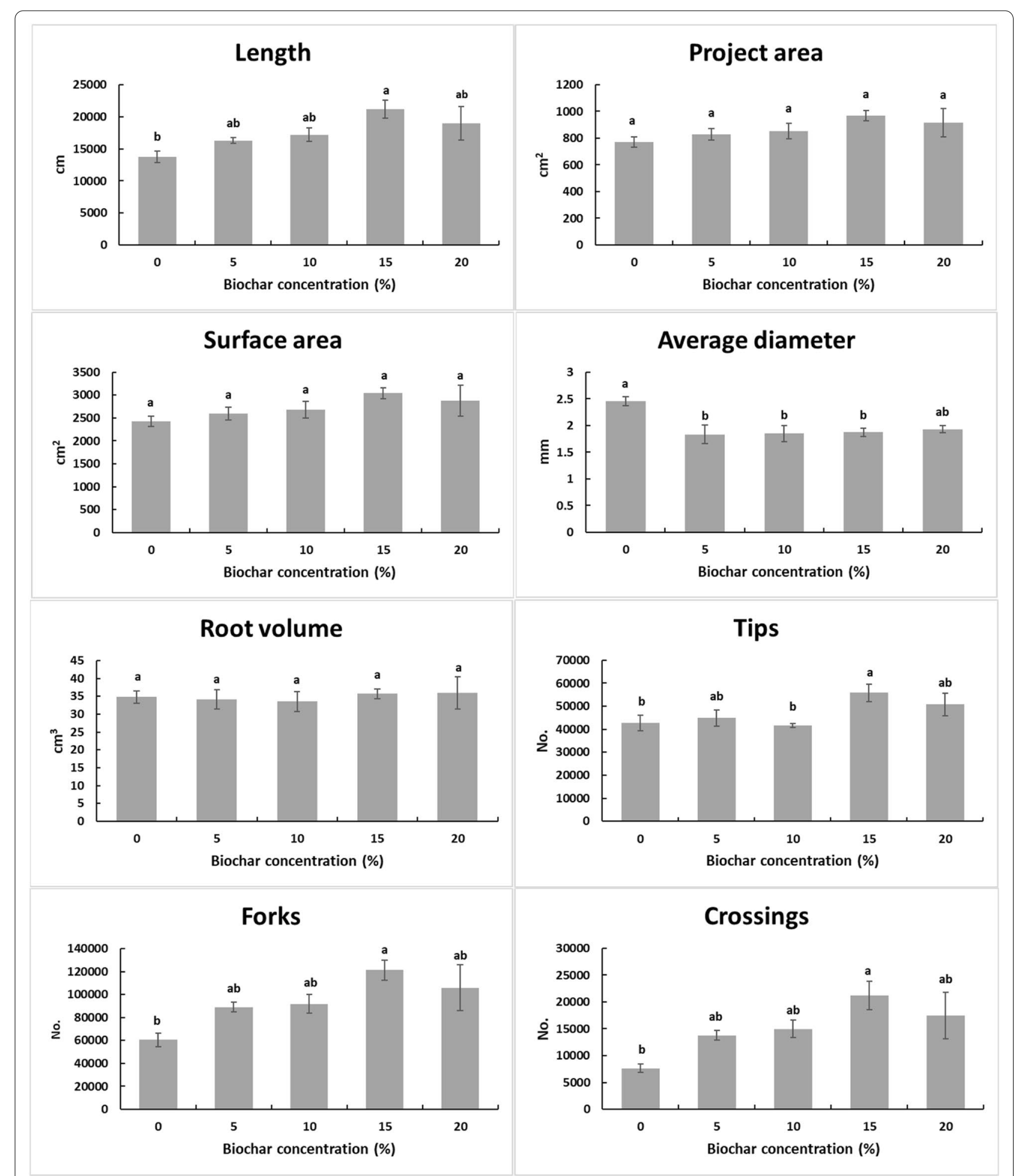

Fig. 3 Root traits of muscadine from columns. Bars with the same letters indicate that the least square means are not significantly different $(P \leq 0.05)$ according to the Tukey-Kramer test 
number of forks and crossings. However, there were no differences between 0 and 5\% biochar-amended treatments. Similarly, there were no significant differences among $10 \%, 15 \%$, and $20 \%$ biochar-amended treatments (Fig. 2). The results from the current study confirmed that pinewood biochar application can promote muscadine grape root growth in the early growth stage. Masahide et al. found that bark biochar significantly increased the root volume, or biomass, and colonization rate of arbuscular mycorrhizal (AM) fungi in maize [54]. Ishii and Kadoya [55] also reported an increase in root biomass after charcoal application. The reason may be that the biochar application increases soil water retention [56] and the gaseous phase [57]. Specifically, amelioration of the soil physical and chemical properties could be effective in enhancing root growth. It has been previously reported that biochar-type materials can promote root growth [58]. In addition, roots can even grow into biochar pores [59, 60]. Makoto et al. [61] showed a significant increase in both root biomass (47\%) and root tip number (64\%) within a carbonized layer from forest fire, with larch twigs, birch twigs, and shoots of dwarf bamboo. Furthermore, with the improvement of biochar, the root length of rice also increased [62]. Therefore, not only the abundance but also the growth behavior of roots may be changed by the presence of biochar [49].

Muscadine root traits measured in the column study are presented in Fig. 3. There were no differences among treatments regarding project area, surface area, or root volume. Overall, root length, average diameter, number of root tips, forks, and crossings reached the highest value at $15 \%$ biochar amendment and the lowest value without biochar application. Interestingly, in the control group, the root length had a similar surface area, but the average diameter was more substantial than other treatments. This means the roots were thicker in the control, while the roots from other treatments were finer. Fine roots, also known as feeder roots, are functional component and responsible for resource acquisition. Therefore, biochar can promote feeding root development, which is consistent with our observation. The reduced diameter of roots can be explained by more root occupancy of soil pore space [63]. The largest root length and the highest number of root tips, forks, and crossings were found at $15 \%$ biochar amendment. However, there was no significant difference in root length in other treatments. The root project area, surface area, and root volume were not affected by treatments. A similar study also reported that the incorporation of biochar can increase the root depth of barley in coarse sandy soil [64]. One of the major factors determining root growth is soil mechanical resistance, including soil texture, moisture, and bulk density [65]. Sandy soil shows high resistance of root growth due to large bulk density, poor structure, and low compressibility. However, biochar amelioration may offset some of these properties. From literature, biochar reduced soil bulk density and increased soil compressibility [66], making the soil easier for root development. In addition, biochar improved soil WHC, thus increasing the amount of soil moisture content. Higher soil moisture can also reduce mechanical resistance and increase the amount of available water for plants. Generally, the mechanism of how biochar improves crop root growth might be by modifying soil structure, especially for bulk density, and improving soil WHC to reduce mechanical resistance [67].

\section{Conclusion}

Biochar amendment had a strong impact on soil physical properties, such as moderating soil thermal properties, buffering soil $\mathrm{pH}$, improving soil $\mathrm{WHC}$, and decreasing soil bulk density. Since biochar lowered soil bulk density, thereby increasing soil porosity and soil aeration, it may have positive effects on roots. Furthermore, biochar improved root length, project area, surface area, the number of forks, and crossings significantly. Plants without biochar incorporation had shorter and thicker roots than those grown with biochar, suggesting that biochar could facilitate formation of finer and longer roots. If economically viable, biochar could potentially be used as the best management practice for muscadine production, particularly in sandy soils with low nutrient and WHC; however, more research is needed to explore the impact of biochar from different feedstocks with different incorporation rates at various growth stages under field conditions.

\section{Abbreviations}

WHC: Water-holding capacity; SEM: Scanning electron microscopy.

\section{Acknowledgements}

The Florida Department of Agriculture and Consumer Services are acknowledged for financial support of this study. The authors thank Dustin Huff and stone fruit labs in the Horticultural Sciences Department at the University of Florida for their assistance during laboratory and greenhouse experiments.

\section{Authors' contributions}

The authors declare that they have no known competing financial interests or personal relationships that could have appeared to influence the work reported in this paper. YC was involved in formal analysis, investigation, writing--original draft, project administration. $L R, L Z, B G$, and MAS were involved in writing--review and editing, resources. AS was involved in supervision, writing--review and editing, resources, and validation. All authors read and approved the final manuscript.

\section{Funding}

Not applicable.

\section{Availability of data and materials}

All data generated or analyzed during this study are included in this published article. 
Ethics approval and consent to participate

Not applicable.

\section{Consent for publication}

Not applicable.

\section{Competing interests}

The authors declare that there are no conflicts of interest. The authors have not received funding or benefits from industry or elsewhere to conduct this study.

\section{Author details}

${ }^{1}$ Horticultural Sciences Department, University of Florida, Gainesville, FL 32611, USA. ${ }^{2}$ Horticultural Sciences Department, University of Florida, Institute of Food and Agricultural Sciences, Indian River Research and Education Center, Ft. Pierce, FL 34945, USA. ${ }^{3}$ Agricultural and Biological Engineering Department, University of Florida, Gainesville, FL 32611, USA. ${ }^{4}$ Department of Agriculture, Nutrition, and Food Systems, University of New Hampshire, Durham, NH 03824, USA

Received: 7 September 2020 Accepted: 24 December 2020

Published online: 27 January 2021

\section{References}

1. Lehmann J. A handful of carbon. Nature. 2007;447(7141):143-4

2. Hu X, Ding Z, Zimmerman AR, Wang S, Gao B. Batch and column sorption of arsenic onto iron-impregnated biochar synthesized through hydrolysis. Water Res. 2015;68:206-16.

3. Rawat J, Saxena J, Sanwal P. Biochar: a sustainable approach for improving plant growth and soil properties. Biochar-an imperative amendment for soil and the environment: IntechOpen; 2019.

4. Yu H, Zou W, Chen J, Chen H, Yu Z, Huang J, et al. Biochar amendment improves crop production in problem soils: a review. J Environ Manage. 2019;232:8-21.

5. Palansooriya KN, Ok YS, Awad YM, Lee SS, Sung J-K, Koutsospyros A, et al. Impacts of biochar application on upland agriculture: a review. J Environ Manage. 2019;234:52-64.

6. Yu O-Y, Raichle B, Sink S. Impact of biochar on the water holding capacity of loamy sand soil. Int J Energy Environ Eng. 2013;4(1):44.

7. Alghamdi AG. Biochar as a potential soil additive for improving soil physical properties-a review. Arab J Geosci. 2018;11(24):766.

8. Backer RG, Saeed W, Seguin P, Smith DL. Root traits and nitrogen fertilizer recovery efficiency of corn grown in biochar-amended soil under greenhouse conditions. Plant Soil. 2017:415(1-2):465-77.

9. Amendola C, Montagnoli A, Terzaghi M, Trupiano D, Oliva F, Baronti $S$, et al. Short-term effects of biochar on grapevine fine root dynamics and arbuscular mycorrhizae production. Agr Ecosyst Environ. 2017;239:236-45

10. Razaq M, Shen H-I, Sher H, Zhang P. Influence of biochar and nitrogen on fine root morphology, physiology, and chemistry of Acer mono. Sci Rep. 2017:7(1):1-11.

11. Xiang Y, Deng Q, Duan H, Guo Y. Effects of biochar application on roo traits: a meta-analysis. Gcb Bioenergy. 2017;9(10):1563-72.

12. Laird DA. The charcoal vision: A win-win-win scenario for simultaneously producing bioenergy, permanently sequestering carbon, while improving soil and water quality. Agron J. 2008;100(1):178-81.

13. Jeffery S, Bezemer TM, Cornelissen G, Kuyper TW, Lehmann J, Mommer $L$, et al. The way forward in biochar research: targeting trade-offs between the potential wins. Gcb Bioenergy. 2015;7(1):1-13.

14. Prendergast-Miller MT, Duvall M, Sohi SP. Biochar-root interactions are mediated by biochar nutrient content and impacts on soil nutrient availability. Eur J Soil Sci. 2014;65(1):173-85.

15. Brockhoff SR, Christians NE, Killorn RJ, Horton R, Davis DD. Physical and mineral-nutrition properties of sand-based turfgrass root zones amended with biochar. Agron J. 2010;102(6):1627-31.

16. Busscher WJ, Novak JM, Evans DE, Watts DW, Niandou MAS, Ahmedna M. Influence of pecan biochar on physical properties of a norfolk loamy sand. Soil Sci. 2010;175(1):10-4.
17. Karhu K, Mattila T, Bergstrom I, Regina K. Biochar addition to agricultural soil increased $\mathrm{CH} 4$ uptake and water holding capacity-results from a short-term pilot field study. Agr Ecosyst Environ. 2011;140(1-2):309-13.

18. Busch D, Kammann C, Grunhage L, Muller C. Simple biotoxicity tests for evaluation of carbonaceous soil additives: establishment and reproducibility of four test procedures. J Environ Qual. 2012:41(4):1023-32.

19. Kammann C, Ratering S, Eckhard C, Muller C. Biochar and hydrochar effects on greenhouse gas (carbon dioxide, nitrous oxide, and methane) fluxes from soils. J Environ Qual. 2012;41(4):1052-66.

20. Asai H, Samson BK, Stephan HM, Songyikhangsuthor K, Homma K, Kiyono Y, et al. Biochar amendment techniques for upland rice production in Northern Laos: 1. Soil physical properties, leaf SPAD and grain yield. Field Crops Res. 2009;111(1-2):81-4.

21. Ippolito JA, Laird DA, Busscher WJ. Environmental benefits of biochar. J Environ Qual. 2012:41(4):967-72.

22. Baronti S, Vaccari FP, Miglietta F, Calzolari C, Lugato E, Orlandini S, et al. Impact of biochar application on plant water relations in Vitis vinifera (L.). Eur J Agronomy. 2014;53:38-44.

23. Clough T, Condron L, Kammann C, Müller C. A review of biochar and soil nitrogen dynamics. Agronomy. 2013;3(2):275-93.

24. Ventura M, Sorrenti G, Panzacchi P, George E, Tonon G. Biochar reduces short-term nitrate leaching from a horizon in an apple orchard. J Environ Qual. 2013:42(1):76-82.

25. Buss W, Kammann C, Koyro HW. Biochar reduces copper toxicity in Chenopodium quinoa Willd in a sandy soil. J Environ Qual. 2012:41(4):1157-65.

26. Case SDC, MCNamara NP, Reay DS, Whitaker J. The effect of biochar addition on $\mathrm{N} 2 \mathrm{O}$ and $\mathrm{CO} 2$ emissions from a sandy loam soil — the role of soil aeration. Soil Biol Biochem. 2012;51:125-34.

27. Cayuela ML, Sánchez-Monedero MA, Roig A, Hanley K, Enders A, Lehmann J. Biochar and denitrification in soils: when, how much and why does biochar reduce $\mathrm{N}_{2} \mathrm{O}$ emissions? Sci Rep. 2013;3:1732.

28. Warnock DD, Lehmann J, Kuyper TW, Rillig MC. Mycorrhizal responses to biochar in soil-concepts and mechanisms. Plant Soil. 2007:300(1-2):9-20.

29. Lehmann J, Rillig MC, Thies J, Masiello CA, Hockaday WC, Crowley D. Biochar effects on soil biota-a review. Soil Biol Biochem. 2011;43(9):1812-36.

30. Jin $\mathrm{H}$. Characterization of microbial life colonizing biochar and biocharamended soils. 2010.

31. Husson $\mathrm{O}$. Redox potential (Eh) and $\mathrm{pH}$ as drivers of soil/plant/microorganism systems: a transdisciplinary overview pointing to integrative opportunities for agronomy. Plant Soil. 2013;362(1-2):389-417.

32. Borchard N, Prost K, Kautz T, Moeller A, Siemens J. Sorption of copper (II) and sulphate to different biochars before and after composting with farmyard manure. Eur J Soil Sci. 2012:63(3):399-409.

33. Graber ER, Tsechansky L, Gerstl Z, Lew B. High surface area biochar negatively impacts herbicide efficacy. Plant Soil. 2012;353(1-2):95-106.

34. Gomez-Eyles JL, Beesley L, Moreno-Jimenez E, Ghosh U, Sizmur T. The potential of biochar amendments to remediate contaminated soils. Biochar Soil Biota. 2013;4:100-33.

35. Wan YZ, Schwaninger HR, Baldo AM, Labate JA, Zhong GY, Simon CI. A phylogenetic analysis of the grape genus (Vitis L.) reveals broad reticulation and concurrent diversification during neogene and quaternary climate change. Bmc Evol Biol. 2013;13:141.

36. Comeaux BL, Nesbitt WB, Fantz PR. Taxonomy of the native grapes of North Carolina. Castanea. 1987:52(3):197-215.

37. Pastrana-Bonilla E, Akoh CC, Sellappan S, Krewer G. Phenolic content and antioxidant capacity of muscadine grapes. J Agricult Food Chem. 2003;51(18):5497-503.

38. Luo J, Song S, Wei Z, Huang Y, Zhang Y, Lu J. The comparative study among different fractions of muscadine grape 'Noble'pomace extracts regarding anti-oxidative activities, cell cycle arrest and apoptosis in breast cancer. Food Nutr Res. 2017;61(1):1412795.

39. Hopkins D. Xylella fastidiosa: xylem-limited bacterial pathogen of plants. Annu Rev Phytopathol. 1989;27(1):271-90.

40. Vrsic S, Kocsis L, Pulko B. Influence of substrate pH on root growth, biomass and leaf mineral contents of grapevine rootstocks grown in pots. J Agricult Sci Technol. 2016;18:483-90. 
41. Laird DA, Fleming P, Davis DD, Horton R, Wang B, Karlen DL. Impact of biochar amendments on the quality of a typical Midwestern agricultural soil. Geoderma. 2010;158(3-4):443-9.

42. Koide RT, Nguyen BT, Skinner RH, Dell CJ, Peoples MS, Adler PR, et al. Biochar amendment of soil improves resilience to climate change. Gcb Bioenergy. 2015;7(5):1084-91.

43. Vomocil JA. Porosity. Methods of Soil Analysis: Part 1 Physical and Mineralogical Properties, Including Statistics of Measurement and Sampling. 1965;9:299-314

44. Zhang Q, Wang Y, Wu Y, Wang X, Du Z, Liu X, et al. Effects of biochar amendment on soil thermal conductivity, reflectance, and temperature. Soil Sci Soc Am J. 2013;77(5):1478-87.

45. Liu C, Wang H, Tang X, Guan Z, Reid BJ, Rajapaksha AU, et al. Biochar increased water holding capacity but accelerated organic carbon leaching from a sloping farmland soil in China. Environ Sci Pollut Res. 2016;23(2):995-1006.

46. Blanco-Canqui H. Biochar and soil physical properties. Soil Sci Soc Am J. 2017;81(4):687-711

47. Basso AS, Miguez FE, Laird DA, Horton R, Westgate M. Assessing potential of biochar for increasing water-holding capacity of sandy soils. Gcb Bioenergy. 2013;5(2):132-43.

48. Downie A, Crosky A, Munroe P. Physical properties of biochar. Biochar for environmental management: Science and technology; 2009. p. 13-32.

49. Yang L, Liao F, Huang M, Yang L, Li Y. Biochar improves sugarcane seedling root and soil properties under a pot experiment. Sugar Tech. 2015;17(1):36-40.

50. Barrow N, Debnath A. Effect of phosphate status on the sorption and desorption properties of some soils of northern India. Plant Soil. 2014;378(1-2):383-95.

51. Penn CJ, Camberato JJ. A critical review on soil chemical processes that control how soil $\mathrm{pH}$ affects phosphorus availability to plants. Agriculture. 2019;9(6):120

52. Miller JO. Soil pH affects nutrient availability. UME FS1054. 2016;10:M2PN59.

53. Xu R-K, Zhao A-Z, Yuan J-H, Jiang J. pH buffering capacity of acid soils from tropical and subtropical regions of China as influenced by incorporation of crop straw biochars. J Soils Sediments. 2012;12(4):494-502.

54. Yamato M, Okimori Y, Wibowo IF, Anshori S, Ogawa M. Effects of the application of charred bark of Acacia mangium on the yield of maize, cowpea and peanut, and soil chemical properties in South Sumatra. Indonesia Soil Sci Plant Nutr. 2006;52(4):489-95.

55. Ishii T, Kadoya K. Effects of charcoal as a soil conditioner on citrus growth and vesicular-arbuscular mycorrhizal development. J Japanese Soc Horticult Sci. 1994;63(3):529-35.
56. Piccolo A, Pietramellara G, Mbagwu J. Effects of coal derived humic substances on water retention and structural stability of Mediterranean soils. Soil Use Manag. 1996;12(4):209-13.

57. Ezawa T, Yamamoto K, Yoshida S. Enhancement of the effectiveness of indigenous arbuscular mycorrhizal fungi by inorganic soil amendments. Soil Sci Plant Nutr. 2002;48(6):897-900.

58. Nutman PS. Host factors influencing infection and nodule development in leguminous plants. Proc R Soc London Series B Biol Sci. 1952;139(895):176-85.

59. Lehmann J, da Silva JP, Steiner C, Nehls T, Zech W, Glaser B. Nutrient availability and leaching in an archaeological Anthrosol and a Ferralsol of the Central Amazon basin: fertilizer, manure and charcoal amendments. Plant Soil. 2003;249(2):343-57.

60. Joseph SD, Camps-Arbestain M, Lin Y, Munroe P, Chia CH, Hook J, et al. An investigation into the reactions of biochar in soil. Aust J Soil Res. 2010:48(6-7):501-15

61. Makoto K, Tamai Y, Kim YS, Koike T. Buried charcoal layer and ectomycorrhizae cooperatively promote the growth of Larix gmelinii seedlings. Plant Soil. 2010;327(1-2):143-52.

62. Noguera D, Rondón M, Laossi K-R, Hoyos V, Lavelle P, de Carvalho $\mathrm{MHC}$, et al. Contrasted effect of biochar and earthworms on rice growth and resource allocation in different soils. Soil Biol Biochem. 2010;42(7):1017-27.

63. Ni J, Chen X, Ng CWW, Guo H. Effects of biochar on water retention and matric suction of vegetated soil. Géotechnique Lett. 2018;8(2):124-9.

64. Bruun EW, Petersen CT, Hansen E, Holm JK, Hauggaard-Nielsen H. Biochar amendment to coarse sandy subsoil improves root growth and increases water retention. Soil Use Manag. 2014;30(1):109-18.

65. Bengough AG, Mullins CE. Mechanical impedance to root growth: a review of experimental techniques and root growth responses. J Soil Sci. 1990:41(3):341-58.

66. Petersen C, Hansen E, Larsen H, Hansen L, Ahrenfeldt J, HauggaardNielsen $\mathrm{H}$. Pore-size distribution and compressibility of coarse sandy subsoil with added biochar. Eur J Soil Sci. 2016;67(6):726-36.

67. Xiao Q, Zhu L-X, Zhang H-P, Li X-Y, Shen Y-F, Li S-Q. Soil amendment with biochar increases maize yields in a semi-arid region by improving soil quality and root growth. Crop Pasture Sci. 2016;67(5):495-507.

\section{Publisher's Note}

Springer Nature remains neutral with regard to jurisdictional claims in published maps and institutional affiliations.

\section{Submit your manuscript to a SpringerOpen ${ }^{\circ}$ journal and benefit from:}

- Convenient online submission

- Rigorous peer review

- Open access: articles freely available online

- High visibility within the field

Retaining the copyright to your article

Submit your next manuscript at springeropen.com 